\title{
Letter to J. S. Kelly, AEC on the Project Sulky Concept
}

G. W. Johnson

\section{RECEIVED}

\section{JAN 211997 \\ DISTRIBUTION OF TIS OSTI}

THIS DOCUMENT B UNLAMTIED

lin

June 29, 1964

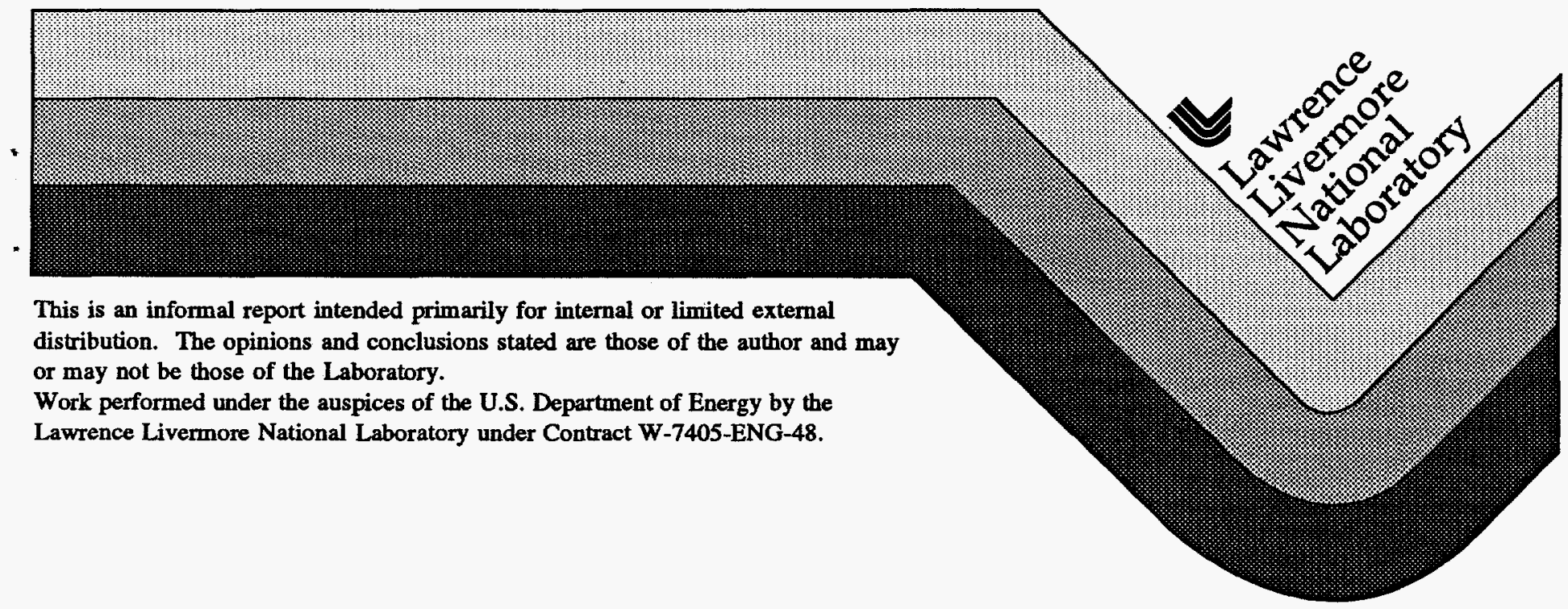




\section{DISCLAIMER}

This report was prepared as an account of work sponsored by an agency of the United States Government. Neither the United States Government nor any agency thereof, nor any of their employees, makes any warranty, express or implied, or assumes any legal liability or responsibility for the accuracy, completeness, or usefulness of any information, apparatus, product, or process disclosed, or represents that its use would not infringe privately owned rights. Reference herein to any specific commercial product, process, or service by trade name, trademark, manufacturer, or otherwise does not necessarily constitute or imply its endorsement, recommendation, or favoring by the United States Government or any agency thereof. The views and opinions of authors expressed herein do not necessarily state or reflect those of the United States Government or any agency thereof. 


\section{DISCLAIMER}

Portions of this document may be illegible in electronic image products. Images are produced from the best available original document. 
LAWRENCE RADIATION LABORATORY P. O. $30 \times 808$ LWERMORE, CALIFORNIA 94551

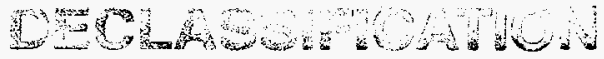

$$
\begin{aligned}
& \text { 3) W }
\end{aligned}
$$

Mr. John S. KeIly

Director, Division of Reacefui Nicled. Expiosives

$$
73 / 327
$$

June 29, 1964

U. S. Atomic Energy Comission

Wasilington 25, D. C.

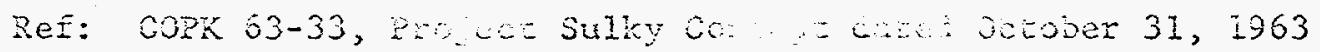

CORK $63-4,2.4$.

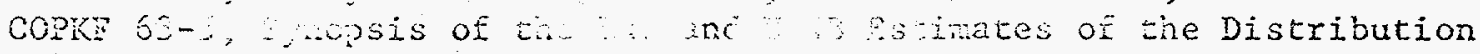

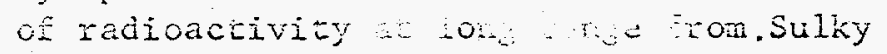

Dear Mr. Keziy:

As you recail, the ioo-ton nuzk... cruceng experiment in hardrock,

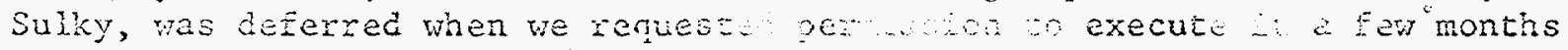

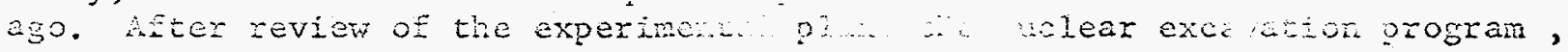
and the importance of nuclear excaviniton we nional objectives for an Isthmian canal, we are convinced the sull $\quad \therefore$ ant should be executed as soon as practical.

There were several questions $z$ : Sulby at the national borders. Whit been informative, no new definitive

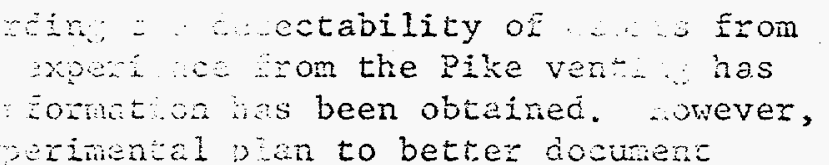
it has been possible to modify the experinental pai to betrer docunent release of radioactivity from sulky. Te are combed that sulky wiI not be detected if it is fired under the nind contions specified du-ne the winter nontis; however, it is poss.. USA. Lil not concur in this conclusion.

Details of both the changes in exerike. al pan and pike venting analysis are included.

We hereby request your appre: originally requested with a rea. activity source aedirements $a$... precision and on wind sect? downind direct. . wis 11 fa:

.c proceec with project Sulky as . ng date of December 3,1964 . The radiosishtiy modified to inprove measurement watheresticted so that the initial

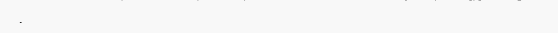
incen 135 and 165 degrey.

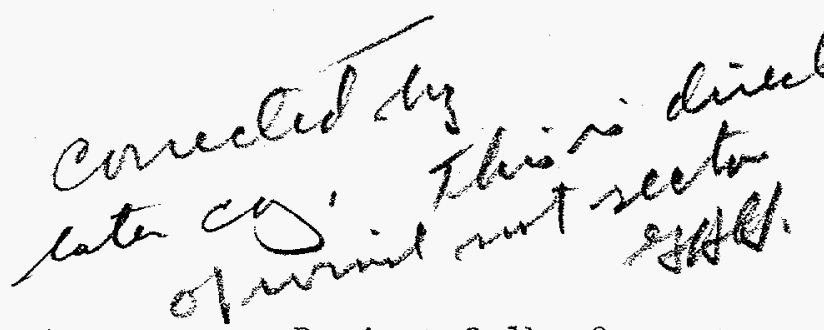

Enci: Appe. An IV wation of the Equivalene Fission Yield Vented from Pike

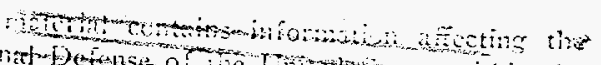

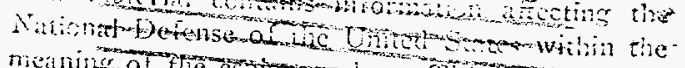

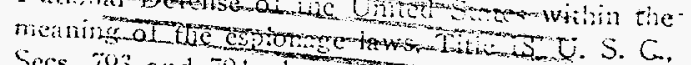
Secs, 793 and 794 , the tinsmissibn- o- revelation of which in any manner to an unationized per-
son is prolibited by law. 


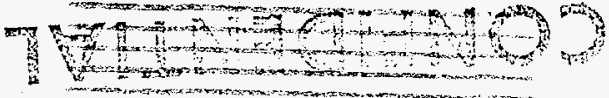

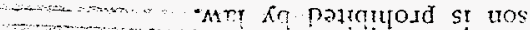

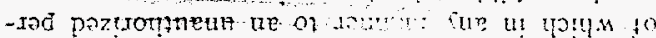

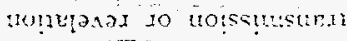
$\because \operatorname{sen} \operatorname{sen} \cos \theta$

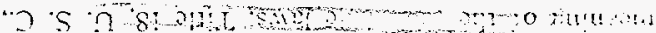

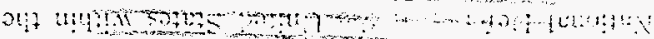

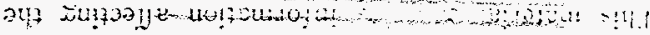

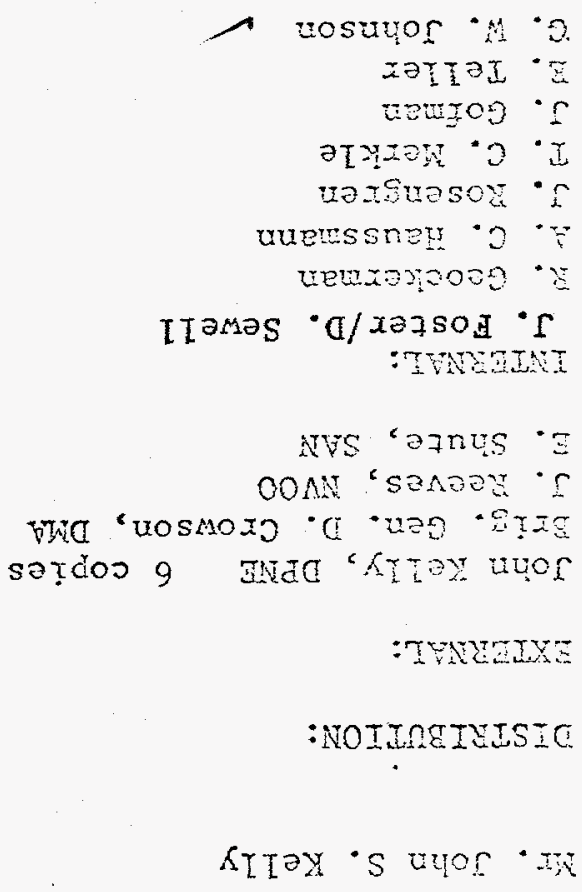




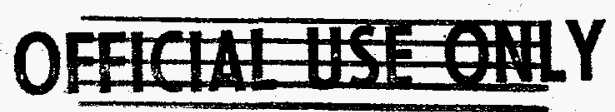

APPENDIX TO THE PROJECT

SULRY CONCEPT

\section{INRRODUCTION}

Since the preparation of the original concept letter additional experience with the detection and evaluation of the Plke vented fraction has Improved our perspective on the problems of detectabllity at longrange and our confldence that most of the debris is deposited close in to the point of detonation.

The objectives of the experiment remain the same:

1. Experimental determination of the vented fraction.

These data are particularly important to the normalization of the theoretical relationships which have been derived to relate depth of burial to the vented fraction for a given medium. A modification of the experinental plan will be made to permit added emphasis on the detemination of the alrborne source strength within a mile or two of ground zero. These data will make $1 t$ possible to speak more specifically to the question of the percentage of the total radioactivity carried to long range by the wind and its prabability of detection at long range.

The USWB will be advised of this change in emphasis of the program, since it is particularly pertinent to the difference of opinion which exists between LRL and the USWB on the partition of the vented activity between that which readily falls out and that which reaches the ground only through convection and diffucton processes. The Pike results were insufficientiy precise to shed any definitive information on the question. Several additional experiments will be required before the problem is well understood. An interpretation of the Pike data is included for reference.

2. Produce data on crater mechanics at a scaled depth greater than Dannyboy.

High-explosive experiments by their very nature are restricted to ylelds that are small compared to what is readily accomplished with 


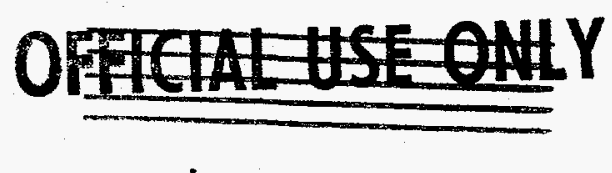

with nuclear explosives. Further, the data will always be suspect because of (a) the uncertainties in the application of scaling relationships and (b) the differences in the nature of the explosions conducted with $\mathrm{HE}$ and $\mathrm{NR}$.

3. Measurement of physical effects of the explosion at Intermediate and long range.

It is always possible that effects other than those attributable to radioactivity may be the linting feature of some specific plowshare application. In order to reduce the probability of there being surprises associated with the physical effects on future applications of nuclear explosives it is important to continue the accumulation of data which define the limits and the magnitude of such effects.

\section{COMPARISON HITH PIKE}

Pike was not a cratering shot nor was it a planned vent; as a result any attempt at comparison of Pike and Sulky must be restricted to comparing the history of the vented radioactive debris.

1. The mechanism of release of radioactive material from these two shots is quite different. Pike is more comparable to the release of material through a long, small diameter pipe than to a venting of material through overburden as it moves upward and outward during the formation of a crater. There is likely to be a considerable difference In particle size distribution. The evidence is that the vented fraction from Pike contained a larger percentage of its activity on small particles than would be expected for sulky. The result in such a case would be that sulky would deposit a larger fraction of the vented activity closer to ground zero, or to put it another way, that a smaller fraction of the vented activity should be carried to long distances.

2. The vented fraction on sulky is expected to be a factor of 5 to 10 smaller than for Plke. Further, Sulky would be shot only under meteorological conditions which would provide the maximum possible residence time for the alrborne debris within the boundaries of the United States. This was not true for Pike. The winds at shot time 


\section{OFFIL UNYY}

were northerly, with minimum velocity and directional shear, and of apprectable speed. These are precisely opposite to the conditions which have been established for conduct of the Sulky experiment.

A careful cholce of wind structure, combined with sulky's smaller vented fraction, should reduce the probability of detection at any border to inglgnificance; in part because of the dilution with distance, and in part because of the small percentage probability of reaching either Mexico or the Pacific Coast if shooting is restricted to the 135 to 165 degree sector (see data included in Table $I$, as extracted from the USWB publication, "A Climatology of 700 mb Trajectories origlnating at the Nevada Test Site," dated March 1964).

TABLE I

TRAJECTORY EXIT PROBABILITIES, Dec. Through Eeb.*

\begin{tabular}{lcc} 
TRAJECTORY EXIT & PROBABILITY \% & MEDIAN MUMBER OF DAYS \\
\cline { 2 - 3 } West Canada & 50 & 2.4 \\
E st Canada & 0 & 4.0 \\
Aciantic Ocean & 50 & \\
Gule of Mexico & 0 & \\
Mexico & 0 & \\
Pacific Ocean & 0 &
\end{tabular}

*Por trajectories origlnating at NTS in the 135 to 165 degree sector.

\section{COST AND TIME ESTIMATE}

No changes are anticipated. The modifications to the experimental plan as outlined above are believed to be within the original estimates. 